\title{
Juridical Analysis of the Occupational Safety and Health Management System in the Company
}

\section{Jaminuddin Marbun}

Lecturer in Faculty of Law Darma Agung University, Indonesia

\begin{abstract}
Whatever we do almost all have risks if we are not careful about doing it. Some risks are small and some are large depending on the type of work to be performed. The threat of risk that will occur in this case is the risk of occupational safety and health that cannot be predicted when the event will occur which is clear that each worker must be careful to carry out their work. To overcome the risk of accidents and occupational health it is necessary to hold various efforts by the government, employers and workers to foster norms of protection for workers in accordance with industrial and technological advancements in the company. In order to anticipate workplace accidents in the company, one way is to implement an Occupational Safety and Health Management System that is united with the company's management so that employers can implement fully the protection of workers in employment relationships at the company.
\end{abstract}

\author{
Keywords \\ employers; workers; \\ occupational safety; health \\ management system
}

\section{Introduction}

Humans to meet their needs must work both work in their own or in the property of others by receiving wages to meet their needs and family. Every person who does work must be protected from the dangers that will arise in the work relationship, whether it is injury, injury, death and others. For this reason, every worker always tries to avoid the incident from happening again. Every worker in carrying out their work must receive protection for occupational safety and health in accordance with human dignity and dignity, so that workers feel comfortable and safe working in the company.

Indonesia Government has issued several Manpower Laws along with its regulations, but the Manpower Laws and regulations are not yet complete to regulate all that occurs in employment relations between employers and laborers such as working conditions. The working conditions in this case are the rights and obligations of employers and laborers that have not been fully regulated in the Manpower Laws. In general, there are no stipulations on the working conditions by Manpower Laws because the conditions of companies are not the same as those of working in the morning, working in the evening and at night and the types of companies varying so heterogeneous. The incompleteness of the Manpower Laws and its regulation which UU Law No. 13 of 2003 concerning manpower in article 108 requires employers to employ laborers now less than 10 (ten) people are required to make company regulations which come into force after being ratified by the Minister or Officer designated. (Marbun, 2020)

Around the year 80, Pinius, a Roman Ecyclopedia expert, required that every miner be required to wear a nose cap. Then in 1450 Domonico Fontana was given the task of building the Obelisk in the middle of the St. Pieter Roma, he always requires that workers use helmets as head protectors. So it was very clear before the industrial revolution in Britain and Europe that the issue of occupational safety and health was already the concern of the leaders and figures of the time.

In the Civil Code in Article $1602 \mathrm{w}$ it is stated that the employer is obliged to create occupational safety and health in his company and is fully responsible for any work accident 
unless the work accident is an element of intent. In Law No. 1 of 1970 concerning Occupational Safety and Law No. 13 of 2003 concerning Manpower and other laws and regulations governing occupational safety and health more broadly. Law No.1 of 1970 concerning Occupational Safety, states that the sources of danger are related to the work tools used, workplaces, how they are used and those produced by the company.

In 1933 the firecracker law came out again (Vuur Werk Ordonantie). Furthermore, all the provisions of the laws and regulations issued during the Dutch East Indies era are still valid as long as they do not conflict with applicable Laws. The purpose of labor protection is to prevent work accidents and occupational diseases from occurring because those who work at the company or everyone who enters or is in the company must be protected.

Protection for workers is also regulated in Law No. 3 of 1992 concerning Workers' Social Security which aims to provide protection which includes:

1. Work accident insurance

2. Death Guarantee

3. Old age insurance

4. Health maintenance insurance.

\section{Discussion}

\subsection{Oversight of Occupational Safety and Health}

There is a change from Veiligheids Reglement which is only repressive then Law No. 1 of 1970 concerning Occupational Safety to be preventive which is expected to prevent work accidents and diseases arising from work. Occupational safety and health supervision which was originally only carried out by the government has changed by involving employers and workers in the development and supervision of occupational safety and health.

Supervision of occupational safety and health which has so far only been carried out by the government and then has included employers and workers means that more and more have been involved in overseeing occupational safety and health issues. It should be fulfilled at the time the company is established. The operating requirements are complete.

In making decisions for the implementation of occupational safety and health both at the company level and at the national level it is carried out in a tripartite meaning that it consists of 3 (three) elements, namely elements of employers, elements of labor and elements of government.

Very clear reform in Law No. 1 of 1970 concerning Work Safety include:

1. Expansion of the scope of the law and change of supervision from repressive to preventive and to include employers and workers.

2. Stronger technical formulation.

3. Administrative adjustments needed for supervision.

4. Arrangement of guidance for occupational safety and health for management and workers.

5. Arrangements to establish a committee to guide occupational safety and health and the existence of annual levies from employers to the government.

Then set out some requirements that must be provided and prepared by the entrepreneur. All of this is aimed at avoiding work accidents and occupational diseases. In order to implement protection for workers, a number of obligations for employers are determined, namely obligations for work safety and obligations for occupational health.

To implement work safety protection the employer is obliged to: 
a. Explain to new workers about how to work these workers and understand the dangers of work accidents that will occur in the company and protective equipment that will be used and only then workers can work.

b. To provide guidance to all of its workforce, in accident prevention and fire eradication, providing first aid for accidents and improving occupational safety and health.

c. Establish a Committee for Guidance for Occupational Safety and Health to work together between workers and management in implementing the prevention of accidents and occupational diseases.

d. Make it complete with conditions that must be met by workers and management.

e. Every work that is received or to be transferred must be checked for physical and mental health by a doctor appointed by the employer on a regular basis.

For the protection of occupational health, employers must:

a. The employer must conduct a health check-up for each worker and report it no later than 24 hours if a worker's disease is found.

b. To control hazardous chemicals in the workplace to prevent work accidents and occupational diseases and to provide personal protective equipment.

c. Conducting Company Hygiene and Occupational Health training for Company Doctors and their medical staff held by the Company Hygiene Center and the Regional Corporate Hygiene Office, all of which are under the Ministry of Manpower office.

Anyone does not want an accident because the accident is a disaster that can happen anytime, anywhere, including in the company. If there is a work accident at the company that is a victim is a worker and suffered a loss the employer means that although there is no damage to the company property arising from a work accident, the employer also suffers losses such as paying workers salaries while not attending work due to an accident, paying for medical treatment, etc..

\subsection{Facilities Required to Avoid Occupational Accidents and Occupational Diseases}

In order to guarantee occupational safety and health in all workplaces for workers, in the statutory regulations, several institutional devices have been set up to foster, supervise and implement occupational safety and health in the workplace, including:

1. In order for employers to establish an Occupational Safety and Health Institute to assist employers in carrying out joint duties and obligations in the field of occupational safety and health and also provide consideration and effort to prevent accidents in the company and can provide explanations and information to all workers in the company.

The composition of the board of the Occupational Safety and Health Institute consists of a Chairperson, secretary and members. The Chairperson as the executor of the Guidance for Occupational Safety and Health, while the Secretary leads and carries out the duties of the secretary and carries out the decisions of the Committee for Work Safety and Health. Chair, deputy chairman, secretary and members are professional occupational safety and health workers.

2. Technical Inspection Services Company.

Technical inspection service company is a private company that is appointed and authorized to carry out part of the function of occupational safety and health supervision in terms of inspection and testing of occupational safety techniques in the field of steam aircraft. The implementation and testing of steam aircraft and pressure vessels has been lacking, but with the participation of the private sector, the examination is more perfect. 
The inspection carried out by the private sector starts from the inspection and testing of equipment or technical installations, inspection and testing of workforce health, work environment, consultation and advocacy, guidance and training in occupational safety and health. Occupational safety and health services, among others

a. Consultant in the field of Work Safety;

b. Fabrication, maintenance, repair, and installation of techniques.

c. Inspection and testing of techniques / certifications namely pressure vessels, boilers, lightning suppliers and other equipment and work environment.

d. Destructive testing and non-destructive testing

e. Examination, testing and occupational health services

f. Audits must be carried out both internally and externally.

3. Expert in the field of Occupational Safety and Health

The Ministry of Manpower has the authority to establish Occupational Safety and Health Experts outside the Ministry of Manpower to assist company leaders in organizing and improving labor protection and to comply with work safety norms. The employer is obliged to provide occupational safety and health experts in the workplace whose job is to help supervise the implementation and determine the conditions for occupational safety and health, as well as to keep any information about the company or agency secret obtained in relation to his position. In addition there are also doctors who are related to occupational safety and health, namely advisors appointed by the government to be asked for medical considerations regarding workplace accidents and company doctors who work in companies responsible for the health of workers in the company.

The appointment of experts in the field of work safety must have the following criteria:

a. Have at least an undergraduate education and have knowledge related to work safety for at least 2 years or have a baccalaureate degree and have knowledge in the field of work safety for at least 4 years.

b. Have special expertise in inspection techniques or testing standards and have good physical and mental health and are not physically challenged as evidenced by a medical check-up report.

c. Good behavior, high morale and integrity and have a certificate of graduation to take the test for education and training in occupational safety and health

Occupational safety and health expert education is carried out by the Ministry of Labor or the Occupational Safety and Health Services Company which has received permission from the Ministry of Labor. The appointment as an occupational safety and health expert can be extended by submitting an application by the head of the company to the Ministry of Manpower or an official who has been appointed with the conditions as specified, in addition to being extended it can also be revoked if it no longer meets the requirements.

\subsection{Employee Inspector}

To guarantee the implementation of labor laws, it is necessary to have a labor inspector. The implementation of labor norms is carried out on the orders of all Labor Laws.

In general, the duty of supervisory employees is to oversee all labor laws and issues related to employment.

The labor inspection mechanism starts from the first inspection, periodic inspection which is periodic, and special inspection. This special inspection is carried out if there is a complaint or an incident such as a work accident or a request for an inspection. In addition, there is still another re-examination carried out on the results of the previous inspection if there is a statement of dissatisfaction from what was examined. The re-examination 
procedure is carried out by more senior supervisory staff at the provincial and the Ministry of Manpower levels.

In addition to supervising the implementation of laws and regulations, labor inspectors also have an obligation to report the implementation of ILO Conventions by the Government of the Republic of Indonesia to the ILO Body because ILO Convention No. 81 of 1947 was passed into law by the government.

Until now, Indonesia has ratified 16 ILO Conventions consisting of 8 (eight) on the Basic Rights of Workers and 8 (eight) on General Conventions.

Because Indonesia is already a member of the ILO, there is an obligation for every country that is an ILO member to report the implementation of every ILO Convention ratified by that State. So that labor inspection issues are not only national but also international. In fact, every ILO member country is held accountable at an ILO session held in Geneva.

\subsection{The Role of Work Protection Norms}

In order to get guaranteed protection for every worker and everyone in the work environment must be strived to remain safe. Safeguarding occupational health and safety is carried out by examining and testing the feasibility of the safe use or use of machine or aircraft equipment, installations, materials and processes.

Workforce protection is carried out using a management approach method. This method is very helpful for company leaders to exercise control over the implementation of occupational safety and health in the company and through the occupational safety and health management system, company leaders can find out the extent to which occupational safety and health programs are implemented in their companies.

To implement a management system policy based on Decree of the Minister of Manpower No. PER.05 / MEN / 1996 concerning the Occupational Safety and Health Management System has regulated the organizational structure of the implementation of accident management, the required personnel, the targets to be achieved so that comfort and safety for work can be achieved.

The basic elements of the policy and the Occupational Safety and Health Management System consist of establishing policies, planning, implementing policies, measuring, evaluating performance, reviewing, improving the implementation of an occupational safety and health management system on an ongoing basis by company management.

Seeing the many risks that occur in the company and the existence of knowledge about risk management, certainly the faster the formation of accident management systems and occupational health. This risk control where the role of management is very important, because risk control requires the availability of all resources owned by the company that is controlled by the company's management. In implementing the Occupational Safety and Health Management System in the workplace, it must be done, namely:

a. Make planning, supervision, control and monitoring;

b. Improving the implementation of work safety supervision on an ongoing basis.

To determine the level of success, a performance measurement was carried out in the form of an audit of the Occupational Safety and Health Management System that is systematic and independent and on behalf of the government.

Activities in measuring success are through inspections whose activities are carried out periodically in checking technical completeness. Occupational safety and health inspection is a detailed test of the workplace, machinery, installation or process so that it is certain that accidents will not occur and what action should be taken to overcome them.

In the audit the Occupational Safety and Health Management System is prioritized as a tool to measure the extent to which the system has been implemented. The audit is focused on 
the entire Occupational Safety and Health System in the company environment that is specific to certain aspects, which is to see from the results whether they are in accordance with the standards.

Occupational Safety and Health inspections are more often carried out when compared to the Occupational Safety and Health Management System Audit because it is identifying hazards. By conducting inspections, all deficiencies can be identified, and conducting audits requires a long time because it involves everything in the workplace.

The success and achievements of the Occupational Safety and Health Management System Audit can be assessed from 12 elements. The audit of the Occupational Safety and Health Management System can be distinguished namely internal audit and external audit.

One of the policies in encouraging commitment from company leaders towards occupational safety and health is by giving awards to companies that have zero occupational accidents to zero and awarding gold or silver certificates for employers who have carried out to a certain point.

The measurement of the implementation of the Occupational Safety and Health Management System is measured as follows:

1. Achievement rate of application of $0 \%-59 \%$ of the required audit criteria and violations of legislation is subject to punishment.

2. At the level of achievement of the application of $60 \%-84 \%$ of the audit criteria required to be awarded.

3. For the achievement of more than $84 \%$ of the audit criteria required to be given a certificate and a gold flag.

The benefits of the Occupational Safety and Health Management System audit for companies, workers, and government are as follows:

1. Benefits of the Occupational Safety and Health Management audit system for companies include:

a) Knowing the extent to which employers have carried out occupational safety and health management;

b) Knowing the effectiveness, efficiency and shortcomings of the application of the Occupational Safety and Health Management System;

c) Improve the company's image and ultimately will improve the company's competitiveness;

d) Increasing the awareness and knowledge of workers regarding occupational safety and health;

e) Prevention of hazards and risks in the company;

f) Prevent greater losses at the company that will be caused by work accidents.

2. Audit benefits for workers include:

a) Cause peace of work in the company;

b) Increase work productivity;

c) Reducing the occurrence of work accidents for workers;

d) Raising workers' awareness of the importance of occupational safety and health;

e) Increase workers' knowledge about the importance of protecting labor.

3. The uses of the audit for the government include:

a) One tool for protecting labor rights in the field of occupational safety and health;

b) To reduce the number of work accidents;

c) To find out the company's compliance with laws and regulations;

d) Improve the image of the nation in international forums.

For work security and everyone who is at work is always safe and sound, hazardous work must be controlled properly so that the company runs well. 


\section{Conclusion}

1. Employers must try to prevent accidents and occupational diseases.

2. Occupational Safety and Health Management System functions to prevent work accidents and occupational diseases in the workplace.

3. The Occupational Safety and Health Management System are very useful for workers, employers and the government to prevent occupational accidents and occupational diseases.

4. The Occupational Safety and Health Management System is part of company management.

\section{References}

Asosiasi Hubungan Industrial Indonesia (2004). Himpunan Peraturan Perundang-undangan Ketenagakerjaan Masa Reformasi, Jakarta

Kementerian Ketenagakerjaan Republik Indonesia. (2017). Kumpulan Modul K3, Direktorat Pengawasan Norma Keselamatan dan Kesehatan Kerja Direktorat Jenderal Pembinaan Pengawasan Ketenagakerjaan dan K3.Jakarta.

Kumpulan Peraturan Ketenagakerjaan dibidang Kesepakatan, Pemutusan, Perlindungan, Perselisihan Hubungan Industrial dan Perjanjian Tenaga Kerja, (2001). Jakarta: CV. Myda.

Marbun, J. (2014). Manfaat Perjanjian Kerja Bersama Dalam Hubungan Industrial Bagi Pengusaah dan Pekerja dan Pekerja/Buruh, Medan: USU Press.

Marbun, J. (2020). The Juridical Analysis between Collective Labor Agreements between Employers and Trade Labor Unions in the Company. Budapest International Research and Critics Institute (BIRCI-Journal), P. 303-310.

Simanihuruk, M.S.M. (2006). Reformasi Pengawasan Ketenagakerjaan, Dewan Pimpinan Pusat Asosiasi Pengawas Ketenagakerjaan, Jakarta.

Simanjuntak, P.J. (2003). Manajemen Hubungan Industrial, Jakarta: Pustaka Sinar Harapan

Soepomo, I. (1992). Pengantar Hukum Perburuhan, Jakarta: Djambatan

Soetrisno, H., (2007). Perkembangan Hubungan Industrial Di Indonesia, Jakarta: Ikatan Perantara Hubungan Industrial Indonesia (IPHI)

Suryani, A.I., \& Suharyanto, A, (2016). Implementasi Program Badan Penyelenggara Jaminan Kesehatan (BPJS) Dalam Meningkatkan Pelayanan Administrasi Kesehatan di Rumah Sakit Umum Sibuhuan Kabupaten Padang Lawas, Jurnal Administrasi Publik Universitas Medan Area, 4 (1): 86-

Suwarto, (2003). Hubungan Industrial Dalam Praktek, Jakarta: Hubungan Industrial Indonesia 